\title{
Structuring ampelographic collections by phenotypic characteristics and comparing the reaction of grape varieties to climate change
}

\author{
L.Yu. Novikova ${ }^{1} \otimes$, L.G. Naumova ${ }^{2}$ \\ ${ }^{1}$ Federal Research Center the N.I. Vavilov All-Russian Institute of Plant Genetic Resources (VIR), St. Petersburg, Russia \\ ${ }^{2}$ All-Russian Research Institute named after Ya.I. Potapenko for Viticulture and Winemaking - Branch of Federal Rostov Agricultural Research Center, \\ Novocherkassk, Russia \\ 凶e-mail: I.novikova@vir.nw.ru
}

\begin{abstract}
Modern climate changes task breeders to adapt viticulture to the new natural resource potential of the regions. A necessary condition is the assessment and analysis of current trends in changing the characteristics of contrasting groups of varieties. The aim of the study is to identify homogeneous groups of varieties of an ampelographic collection and to compare the rates of reaction of their agrobiological parameters to climate changes. Material for the study consists of observations of 21 agrobiological characteristics of 109 grape varieties from the Don ampelographic collection named after Ya.l. Potapenko (Novocherkassk) with an observation period from 10 to 36 years in 1981-2017. The sample included Vitis vinifera L. varieties and the $V$. vinifera L. $\times V$. labrusca $L$. and $V$. vinifera $L$. $\times V$. amurensis Rupr. interspecific hybrids, and hybrids from crosses between $V$. vinifera $L$. and several American species. Homogeneous groups of characteristics and varieties are identified by principal component analysis (PCA) and analysis of variance (ANOVA) methods. Trends in changing the agrobiological characteristics of the varieties and groups of varieties are calculated. PCA revealed that the main differentiating factor of the studied fragment of the ampelographic collection is the size of the bunch; the second, the yield; the third, the time of ripening. The values of the factors are contrasting in varieties of different directions of use and taxonomic origin, which was confirmed by ANOVA. The groups of the $V$. vinifer $a \times V$. labrusca and $V$. vinifera $\times V$. amurensis hybrids do not differ significantly from each other in most indicators, exceeding $V$. vinifera varieties in the number of elements of productivity, winter hardiness and yield. Complex hybrids with American species have an intermediate position between these groups exceeding all groups in bunch weight. All groups of cultivars show trends towards a reduction in productive period, an increase in the mass of bunch and yield, sugar content and a decrease in acidity. The $V$. vinifera $\times V$. labrusca hybrids are distinguished by the highest growth rate of the bunch mass caused by a reduction in the duration of active growth and a decrease in the percentage of fruit-bearing shoots. A higher reduction rate of the production period and a decrease in acidity were observed in later varieties. Regression analysis showed that the acceleration of the ripening of grapes is largely due to rising temperatures.

Key words: ampelographic collection; climate change; information system; time series; agrometeorology; adaptability.
\end{abstract}

For citation: Novikova L.Yu., Naumova L.G. Structuring ampelographic collections by phenotypic characteristics and comparing the reaction of grape varieties to climate change. Vavilovskii Zhurnal Genetiki i Selektsii = Vavilov Journal of Genetics and Breeding. 2019;23(6):772-779. DOI 10.18699/VJ19.551

\section{Структурирование ампелографической коллекции по фенотипическим характеристикам и сравнение реакци сортов винограда на изменение климата}

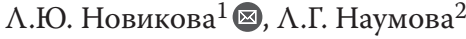 \\ 1 Федеральный исследовательский центр Всероссийский институт генетических ресурсов растений им. Н.И. Вавилова (ВИР), Санкт-Петербург, Россия \\ ${ }^{2}$ Всероссийский научно-исследовательский институт виноградарства и виноделия им. Я.И. Потапенко - филиал Федерального Ростовского аграрного \\ научного центра, Новочеркасск, Россия \\ @e-mail: l.novikova@vir.nw.ru
}

Современные изменения климата ставят задачу адаптации виноградарства к новому природно-ресурсному потенциалу регионов. Необходимым условием для этого являются оценка и анализ современных тенденций изменения агробиологических характеристик контрастных групп сортов. Целью исследования было выделение однородных групп сортов ампелографической коллекции и сравнение скоростей реакции их агробиологических показателей на климатические изменения. Материалом для исследования послужили наблюдения за 21 агробиологическим показателем 109 сортов винограда Донской ампелографической коллекции им. Я.И. Потапенко (г. Новочеркасск) с периодом наблюдения от 10 до 36 лет в 1981-2017 гг. В выборку вошли сорта Vitis vinifera L. и межвидовые гибриды V. vinifera L. $\times$ V. labrusca L., V. vinifera L. $\times$ V. amurensis Rupr., V. vinifera L. с несколькими американскими видами. Методами анализа главных компонент (PCA) и дисперсионного анализа (ANOVA) выделены однородные группы признаков и сортов. Рассчитаны тренды агробиологических показателей сортов и групп сортов. Метод РСА позволил выявить, что главным дифференцирующим фактором изученного фрагмента ампелографической коллекции является крупность грозди, вторым - урожайность, третьим - срок созревания. Значения факторов контрастны у сортов 


\begin{abstract}
разного направления использования и таксономического происхождения, что подтвердил метод ANOVA. Группы гибридов V. vinifera $\times$ V. labrusca и V. vinifera $\times$ V. amurensis достоверно не отличаются друг от друга по большинству показателей, превосходя сорта V. vinifera по количеству элементов продуктивности, зимостойкости и урожайности. Комплексные гибриды с американскими видами занимают по этим признакам промежуточное положение, однако превышают все группы по массе грозди. У всех групп сортов наблюдались тренды к сокращению продукционного периода, увеличению массы грозди и урожайности, росту сахаристости и уменьшению кислотности. Выделяются гибриды V. vinifera $\times$ V. labrusca наибольшей скоростью сокращения продолжительности активного роста, снижением доли плодоносных побегов и увеличением массы грозди. Бо́льшая скорость сокращения продукционного периода и уменьшение кислотности отмечены у более поздних сортов. Регрессионный анализ показал, что ускорение созревания винограда происходит в значительной степени из-за роста температур.

Ключевые слова: ампелографическая коллекция; изменение климата; информационная система; временные ряды; агрометеорология; адаптивность.
\end{abstract}

\section{Introduction}

Modern climate change has become a significant factor for the viticulture in many countries (Jones, 2012; Vršič, Vodovnik, 2012; Quenol et al., 2014). A scientific basis for the program of adapting viticulture to current and expected climate changes are the creation of phenotypic databases of grape genetic resources (Delrot et al., 2019; Hausmann et al., 2019), an assessment of trends in the dynamics of economically important traits (Jones, 2012; Choudhury, Jones, 2014), as well as their modeling and forecasting (Molitor et al., 2014; Quenol et al., 2014). Plant phenology was found to be very sensitive to climate change (Cleland et al., 2007; Santibáñez et al., 2014), and this fact has revived interest in mathematical models of phenology, in particular, to the sum of growing degree days and the sum of effective daily temperatures during the growing season (Cleland et al., 2007; Molitor et al., 2014; Santibáñez et al., 2014). However, the accuracy of phenological models is still insufficient (Richardson et al., 2012).

Previously, the data accumulated from 1981 through 2011 for a sample of 20 grape varieties from the Don ampelographic collection was used in a study of the dynamics of the ripening time duration, which demonstrated uniformity of the varieties' response to changes in agro-climatic factors (Naumova, Novikova, 2013, 2018). To identify the agro-climatic factors determining the development of plants, a regression model (1) was constructed by a method modified for the time series, i. e. pre-differenced variables regression. The analysis in differences allows improving the quality of time series models by removing the agricultural engineering trend (Eliseeva et al., 2007; Sirotenko, 2012; Wenjiao et al., 2013; Iler et al., 2017). The method consists in the regression analysis of the relationship between the annual increments of the indicators, denoted by $\Delta$. It was shown (Naumova, Novikova, 2013, 2018) that duration of the grape ripening time $(N)$ depends on the total temperatures above $20^{\circ} \mathrm{C}\left(\sum T_{20}\right)$ and on duration of the spring period with temperatures of $10-15{ }^{\circ} \mathrm{C}\left(N_{10-15}\right)$ :

$$
\Delta N=-0.154-0.013 \cdot \Delta \sum T_{20}+0.353 \cdot \Delta N_{10-15}, R^{2}=0.69 \text {, ( }
$$

where $R^{2}$ is the equation determination coefficient.

The adaptive potential of a grape plant is strongly dependent on the variety origin (Negrul, 1946; Troshin, 1999; Nosulchak, 2015; Zarmaev, Borisenko, 2018). In the 1960s-1980s, it became clear that the possibilities of intraspecific breeding of the
European-Asian species Vitis vinifera L. had been exhausted, and breeding at the interspecific level was intensified, especially for obtaining varieties resistant to pests, diseases and low temperatures (Nosulchak, 2015). An American and East Asian species $V$. labrusca L. was widely used in breeding for increasing frost, disease and pest resistance, and $V$. amurensis Rupr. for creating early-maturing and frost-resistant varieties (Zarmaev, Borisenko, 2018). When working with large collections, including ampelographic ones, there appear the tasks of evaluating polymorphism, structuring the collections, and identifying homogeneous groups in them, which are solved by multidimensional statistics (Cunha et al., 2009; Leão et al., 2011; Lamine et al., 2014). Previously, the authors have studied dynamics of the main agrobiological indicators observed for at least 5 years and more for 106 varieties of $V$. vinifera $\mathrm{L}$. and hybrids of $V$. vinifera $\mathrm{L} . \times V$. amurensis Rupr., and revealed differences in overwintering factors for the varieties of different origin (Novikova, Naumova, 2018). To date, the authors have expanded the database and created a program for the agrometeorological analysis of time series of observations over a large number of varieties, which allowed the inclusion of a group of other interspecific hybrids in the present study.

The purpose of the study was to identify homogeneous groups of varieties in the ampelographic collection and compare the rates of their agrobiological indicators response to climate change.

\section{Materials and methods}

The materials used in the study were the results of observations in 1981-2017 over 109 grape varieties from the Ya.I. Potapenko Don ampelographic collection. The study was carried out on the accessions with agrobiological data recorded within 10 to 36 years. Four groups of different taxonomic origin were studied (Table 1): varieties and intraspecific hybrids of $V$. vinifera, complex hybrids of $V$. vinifera with several American species (V. rupestris Scheele, V. riparia Michaux, $V$. lincecumii Buckley, etc.); as well as hybrids of $V$. vinifera $\times$ $V$. labrusca; and $V$. vinifera $\times V$. amurensis. According to the type of use, two groups were distinguished, that is, of wine and table varieties. To enlarge these groups, 7 seedless varieties were attributed to the table, and 17 universal varieties to the wine-type ones. The presented varieties have an average ripening time from 99 to 152 days, which corresponds to 6 groups of the international Descriptor list (Code..., 1983). 
Table 1. Distribution of accessions in the studied sample according to the taxonomic origin, type of use, and ripening time

\begin{tabular}{|c|c|c|c|c|c|c|c|c|}
\hline \multirow[t]{2}{*}{ Taxonomic origin } & \multirow[t]{2}{*}{ Type of use } & \multicolumn{7}{|c|}{ Ripening time, days } \\
\hline & & $\begin{array}{l}\text { Super- } \\
\text { early, } \\
<105\end{array}$ & $\begin{array}{l}\text { Very early, } \\
105-115\end{array}$ & $\begin{array}{l}\text { Early, } \\
115-125\end{array}$ & $\begin{array}{l}\text { Mid-early, } \\
125-135\end{array}$ & $\begin{array}{l}\text { Medium, } \\
135-145\end{array}$ & $\begin{array}{l}\text { Mid-late, } \\
145-155\end{array}$ & Total \\
\hline \multirow[t]{2}{*}{ V. vinifera } & Wine & 0 & 1 & 0 & 7 & 19 & 6 & 33 \\
\hline & Table & 4 & 7 & 4 & 5 & 2 & 0 & 22 \\
\hline \multirow{2}{*}{$\begin{array}{l}\text { Hybrids of } V \text {. vinifera with several } \\
\text { American species }\end{array}$} & Wine & 0 & 1 & 0 & 4 & 5 & 2 & 12 \\
\hline & Table & 1 & 1 & 2 & 4 & 8 & 3 & 19 \\
\hline \multirow[t]{2}{*}{ V. vinifera $\times$ V. labrusca } & Wine & 0 & 1 & 1 & 2 & 0 & 1 & 5 \\
\hline & Table & 1 & 1 & 1 & 1 & 0 & 0 & 4 \\
\hline \multirow[t]{2}{*}{ V. vinifera $\times V$. amurensis } & Wine & 0 & 0 & 2 & 3 & 3 & 1 & 9 \\
\hline & Table & 1 & 1 & 2 & 1 & 0 & 0 & 5 \\
\hline
\end{tabular}

Eighty-two varieties are cultivated as the covered and 27 as then the non-covered crop.

The study was carried out on varieties grafted onto the Kober $5 \mathrm{BB}(V$. berlandieri $\times V$. riparia $)$ rootstock. The plant spacing of $3.0 \times 1.5 \mathrm{~m}$ was used, and no irrigation provided. Ground water occurred at a depth of $15-20 \mathrm{~m}$ and did not affect the development of vines. The used grape cultivation technology was common for the northern zone of industrial viticulture in the Russian Federation. The study of grape varieties (agrobiological characteristics measurement and calculation of indicators) was carried out using the methods commonly used in viticulture (Lazarevsky, 1963). The sugar content of berry juice and the titrated acidity were determined according to GOSTs. Twenty-one agrobiological indicators have been analyzed (Table 2), and the data from the weather station of the Ya.I. Potapenko Institute of Viticulture and Winemaking used.

The application of Statistica 13.0 (StatSoft Inc.) helped to reveal the main differentiating factors and contrasting groups of varieties by using the method of principal component analysis (PCA). The analysis of variance was applied to investigate the influence of the factors of taxonomic origin, type of use, and ripening time. The post hoc comparisons were made by the Tukey's test. Many agrometeorological studies of grapes employ the 'average varieties' notion (Davitaya, 1952; Lazarevsky, 1961), i. e., the annual data averaged for homogeneous varieties. The 'average varieties', i. e., the annual indicators averaged for a group, have been calculated for each of the identified homogeneous groups.

The VITIS TIME SERIES (VTS) program has been developed in Delphi 2006 for storing and analyzing the time series data from observations over agrobiological indicators. VTS was used for calculating agro-climatic characteristics for the years of observation (dates of temperature transition above $5,10,15,20,25{ }^{\circ} \mathrm{C}$ (Kelchevskaya, 1971), the sum of temperatures and precipitation for the periods between them), as well as the sums of temperatures for the varieties' interphase periods. The main tendencies in the dynamics (linear trends) in agrometeorological characteristics and agrobiological indicators of varieties and 'average varieties' have been determined. The trends were calculated as coefficients of linear dependence of the studied characters on the year (Eliseeva et al., 2007) and for convenience expressed as units per 10 years. Model (1) was validated by comparing the calculated and actual values for 2012-2017 which were not used in the model creation. By using model (1), the temperature-dependent trend in the ripening time duration was calculated. The significance level for a study was set at $5 \%$.

\section{Results}

Homologous groups identification. Principal component analysis. The PCA for 21 agrobiological indicators allowed identifying three factors which explain $28.9,20.0,18.1 \%$, and the total of $67 \%$ of the variance, with eigenvalues of $6.1,4.2$, 3.8 (totaling 14.1). A scree plot of factor eigenvalues is given in Supplement $1^{1}$. The main factor differentiating varieties in the studied sample from the ampelographic collection are the bunch characteristics (Table 2), such as the bunch mass, the berry mass, the bunch length and width, and the berry length and width. There is a negative relation between sugar content and this factor. In terms of the first factor, there is a contrast between the groups of table and wine varieties (the level of significance between differences of the factor mean values is $p=0.000$, Fig. 1). Supplement 2 presents the designations of the type of use and the origin of varieties in different figures.

The second factor is the yield and the positively associated with it percentage of bud breaks and the number of productivity elements, as well as the negatively associated date of the bud breaking onset. In terms of the second factor, there is a contrast between the varieties of $V$. vinifera and hybrids with $V$. labrusca and $V$. amurensis (Fig. 1), which are characterized by higher yields, high winter-hardiness, early bud break, a higher percentage of fruiting shoots and fruiting coefficient. The groups of $V$. vinifera $\times V$. amurensis and $V$. vinifera $\times V$. labrusca varieties do not differ between themselves by either the first factor $(p=0.741)$ or the second one $(p=0.087)$. At the same time, the average value of the second factor in all interspecific hybrids was significantly higher than that of $V$. vinifera ( $p=0.000$ for the hybrids with $V$. amurensis and V. labrusca; $p=0.006$ for complex hybrids).

\footnotetext{
${ }^{1}$ Supplementary Materials $1-4$ are available in the online version of the paper: http://www.bionet.nsc.ru/vogis/download/pict-2019-23/appx17.pdf
} 
Table 2. Factor loads of 21 agrobiological indicators

\begin{tabular}{|c|c|c|c|}
\hline Indicator & Factor 1 & Factor 2 & Factor 3 \\
\hline Onset of bud break & 0.050 & -0.654 & 0.096 \\
\hline Onset of bud break - onset of flowering & 0.541 & -0.112 & -0.125 \\
\hline Onset of flowering - veraison & -0.120 & -0.524 & 0.613 \\
\hline Veraison - full maturity of berries & -0.204 & -0.433 & 0.702 \\
\hline Ripening time & -0.089 & -0.584 & 0.741 \\
\hline Number of budbreaks, $\%$ & -0.354 & 0.622 & 0.276 \\
\hline Number of normally developed shoots & -0.478 & 0.420 & 0.206 \\
\hline Average bunches per developed shoot & -0.534 & 0.614 & 0.427 \\
\hline Average bunches per productive shoot & -0.413 & 0.488 & 0.349 \\
\hline Number of productive shoots, $\%$ & -0.549 & 0.592 & 0.410 \\
\hline Shoot productivity & 0.480 & 0.522 & 0.497 \\
\hline Yield per vine & 0.086 & 0.757 & 0.491 \\
\hline Bunch mass & 0.907 & 0.017 & 0.137 \\
\hline Bunch length & 0.707 & 0.174 & 0.101 \\
\hline Bunch width & 0.730 & 0.270 & 0.148 \\
\hline Berry mass & 0.855 & 0.119 & 0.297 \\
\hline Berry length & 0.831 & 0.065 & 0.276 \\
\hline Berry width & 0.782 & 0.198 & 0.163 \\
\hline Sugar content & -0.639 & -0.249 & 0.003 \\
\hline Total acidity & -0.192 & -0.466 & 0.718 \\
\hline Glucoacidometric index, GAl; sugar to acidity ratio & -0.118 & 0.372 & -0.718 \\
\hline
\end{tabular}

Note. The marked loads are above 0.70 .

The third factor is the duration of the ripening time and interphase periods. There is a positive relation of acidity and negative of the glucoacidometric index (GAI) with this factor.

Analysis of variance. The influence of the type of use, taxonomic origin and the duration of the ripening time on the main indicators differentiating varieties within the sample was confirmed by the variance analysis. Fig. 2 shows the three main indicators identified by PCA for 8 groups composed according to the origin and type of use.

The two-factor analysis of variance showed that table varieties within the studied sample have, on the average, a significantly shorter ripening time (124 days) than the wine varieties ( 136 days, $p=0.000$ ), and a higher bunch mass ( 300 and $196 \mathrm{~g}$, respectively, $p=0.000$ ). There are no significant differences in yield (4.7 and $4.1 \mathrm{~kg}, p=0.094)$.

The taxonomic origin distinguished the group of $V$. vinifera $\times V$. labrusca and $V$. vinifera $\times V$. amurensis hybrids, which did not differ significantly from each other by the average values of the ripening time duration (123 and 127 days, respectively, $p=0.834)$, yield (6.8 and $5.8 \mathrm{~kg}, p=0.491)$ and the bunch mass (190 and $210 \mathrm{~g}, p=0.943$ ). If compared with $V$. vinifera hybrids, those with $V$. labrusca and $V$. amurensis are characterized on the average by higher yields $(3.7 \mathrm{~kg}$ for $V$. vinifera, $p=0.000$ for both groups), a lower bunch mass (235 g for $V$. vinifera, $p=0.450$ for hybrids with V. labrusca and $p=0.758$ for $V$. amurensis). Also, there was no difference in the ripening time duration (131 days for $V$. vinifera, $p=0.199$ and $p=0.637$ ). Complex hybrids with American species are a very polymorphic group, which, on the average,

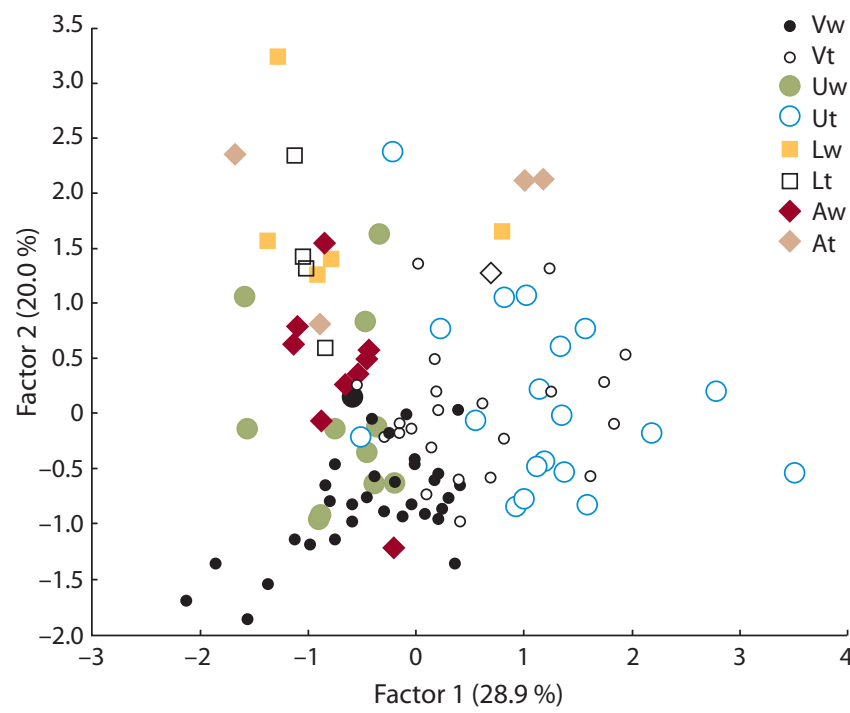

Fig. 1. 109 varieties in the space of the first two PCA factors.

Hereinafter: $\mathrm{w}$ - wine varieties, $\mathrm{t}$ - table varieties. Vw, Vt $-\mathrm{V}$. vinifera, wine, table; Uw, Ut - hybrids with several American species, wine, table; $\mathrm{Lw}$, Lt $-V$. vinifera $\times$ V. labrusca, wine, table; $\mathrm{Aw}$, At $-V$. vinifer $\times$ V. amurensis, wine, table.

exceeds other groups by bunch mass (292 g, $p=0.010$ when compared with $V$. vinifera, and $p=0.018$ in comparison with hybrids with $V$. labrusca and $V$. amurensis). Concerning most indicators, these hybrids occupy an intermediate position between $V$. vinifera varieties and hybrids with $V$. labrusca and 

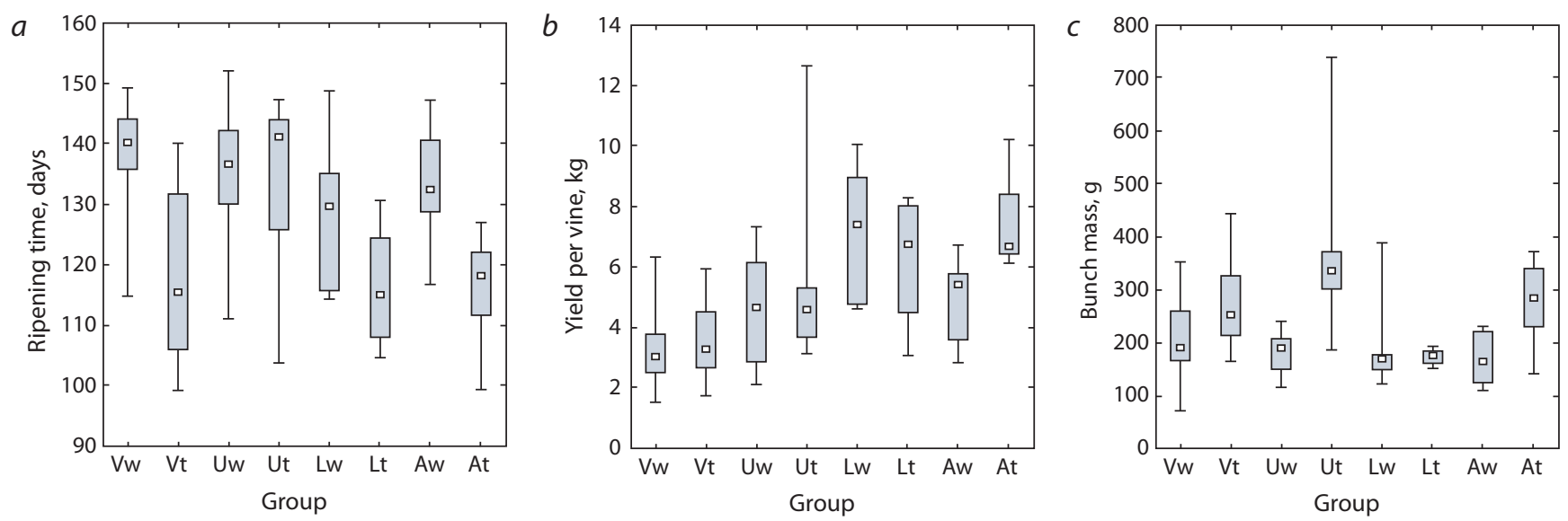

Fig. 2. Economically important characters of grape groups of different taxonomic origin and type of use: $a$, ripening time; $b$, yield per vine; $c$, bunch mass.

$V$. amurensis. If compared with $V$. vinifera varieties, complex hybrids are characterized on the average by higher yields $(4.8 \mathrm{~kg}, p=0.001)$, while they do not differ in the ripening time duration (135 days, $p=0.411$ ).

The analysis of variance of six groups differing by the ripening time (see Table 1) confirmed the PCA-detected reliable association of the ripening time only with the interphase periods, acidity, and GAI. The average duration of the 'onset of flowering - veraison' period increases from 40 days in the group of super-early varieties up to 64 days for the mid-late ones, and that of the 'veraison - full maturity of berries' period from 25 days for super-early to 44 days for the mid-late varieties. The average acidity of the berries grows from $6.4 \mathrm{~g} / \mathrm{dm}^{3}$ in the group of super-early up to $10.2 \mathrm{~g} / \mathrm{dm}^{3}$ in the group of mid-late ones, and GAI decreases from 3.0 to 1.9 units accordingly.

Trends in agrobiological indicators. In 1981-2017, in Novocherkassk, the growing degree days for the period with temperatures above $10^{\circ} \mathrm{C}$ has increased by $170{ }^{\circ} \mathrm{C}$ per 10 years, the amount of precipitation unreliably decreased over this period by $21 \mathrm{~mm}$, the average temperature of the winter dormancy period (October 15 - April 15) has reliably increased by $0.5{ }^{\circ} \mathrm{C} / 10$ years, while the number of days during the winter with temperatures below $-20{ }^{\circ} \mathrm{C}$ has not significantly changed. Trends were calculated for each trait of each variety, however, for most traits and most varieties trends were insignificant against the year-to-year fluctuations. The trends of the 'average varieties' in 8 groups composed according to the taxonomic origin and type of use demonstrated reliable values for a number of indicators (Fig. 3, Supplement 3). Berry quality indicators showed nonlinear dynamics: sugar content was decreasing till the mid-1990s and then started increasing, while acidity was at its maximum in the 1990s (Novikova, Naumova, 2013), therefore their trends have been calculated starting from 1995 .

The groups of varieties composed according to the taxonomic origin and type of use are characterized by the same direction of change of the economically important traits, though with some exceptions. The onset of bud break does not change reliably in any group. The ripening time shortens in all groups and for the 'average variety' from 109 accessions for 2 days/10 years due to the shortening of all interphase periods. The yield increases in all groups of varieties by $1 \mathrm{~kg} / \mathrm{vine} / 10$ years, on the average; the bunch mass increases by $10.2 \mathrm{~g} / 10$ years, on the average; the sugar content increases by $2 \mathrm{~g} / 100 \mathrm{~cm}^{3}$, on the average, and GAI does likewise by 0.6 units/10 years on the average, while acidity decreases by $1 \mathrm{~g} / \mathrm{dm}^{3}$, on the average. The sum of temperatures for the ripening time has increased by $71^{\circ} \mathrm{C} / 10$ years, on the average, due to the growth of excess temperatures in mid-summer.

The group of wine hybrids with $V$. labrusca is distinguished by the highest rate of the ripening time reduction (18 days/10 years) due to shortening of all the interphase periods, including the 'onset of flowering - veraison' period ( 6 days/10 years), which, on the average, does not change in a sample of 109 varieties. The sum of temperatures for all the interphase periods and the ripening time for this group decreases on the whole by $140{ }^{\circ} \mathrm{C} / 10$ years. The percentage of fruiting shoots reliably decreases (by $11.1 \% / 10$ years) only in wine hybrids with $V$. labrusca, which leads to the highest growth rate of the mass of the bunch ( $73 \mathrm{~g} / 10$ years) and berry ( $3 \mathrm{~g} / 10$ years) among the studied groups.

An analysis of trends in groups of different ripening time (Supplement 4) showed that even with such a division into groups, the direction of trends in different groups basically coincides. The early-medium, medium and mid-late varieties have a higher rate of the ripening time reduction (4-5 days/10 years) than the super-early, very early and early ones ( $2-3$ days/10 years). Acidity decreases more rapidly (by $2 \mathrm{~g} / \mathrm{dm}^{3 / 10}$ years) in medium and mid-late varieties than in super-early and very early $\left(0.3-0.4 \mathrm{~g} / \mathrm{dm}^{3} / 10\right.$ years $)$ and in early and early-medium ones ( $1 \mathrm{~g} / \mathrm{dm}^{3} / 10$ years $)$, which is obviously related to the growing heat availability during the ripening of berries.

Model analysis of the ripening time duration. The observed trends may have contributions from such factors as climate change, agricultural engineering trends, and age-related changes of the bushes. To assess the contribution of climate change to the trend of the ripening time duration, a regression model (1) was used. At first, model (1) was checked using the data of 2012-2017, which was not used in its creation, the data calculated applying model (1) and the actual annual increments $(\Delta N)$ (Fig. 4). 

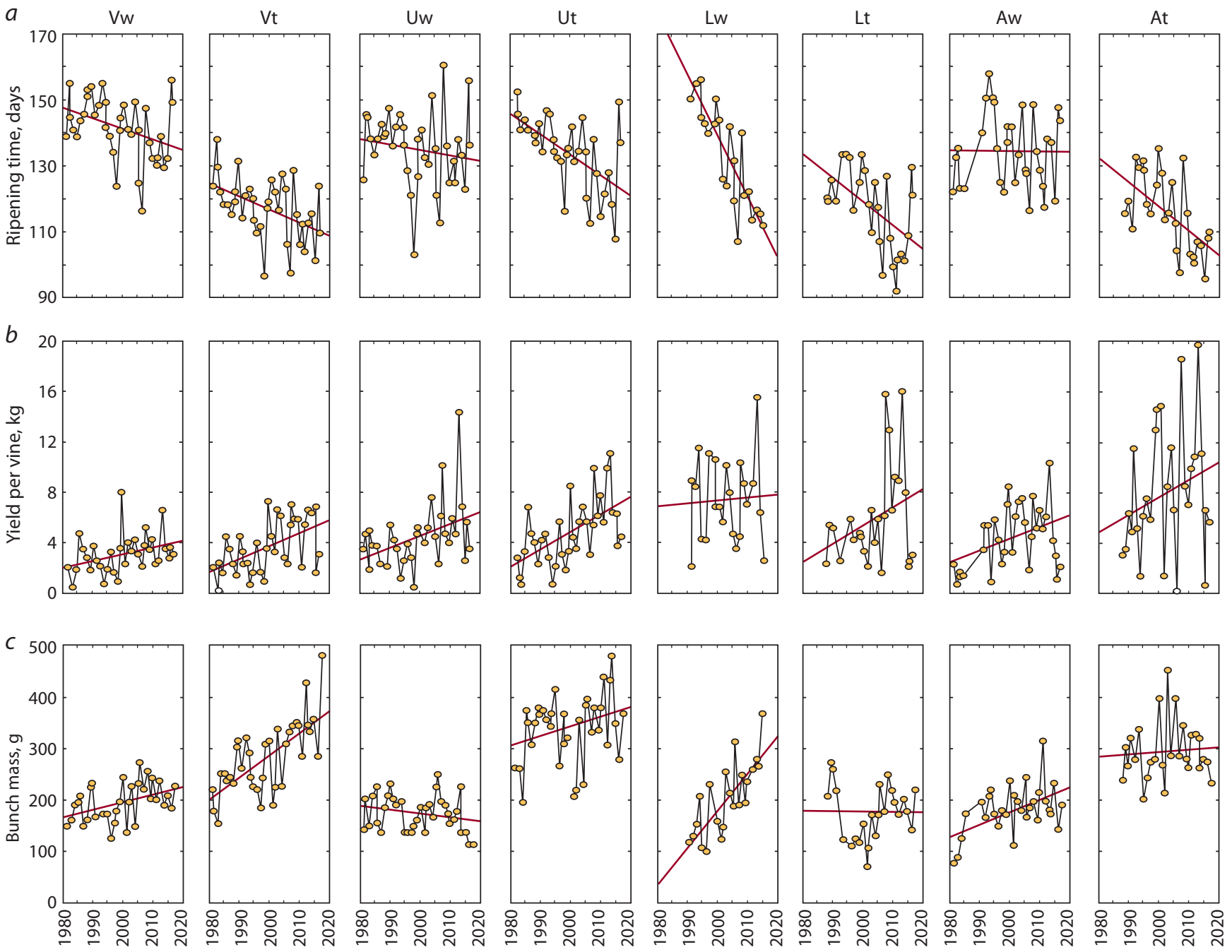

Year

Fig. 3. Trends of economically important characters in grape groups of different taxonomic origin and type of use, 1981-2017, units per 10 years: $a$, ripening time; $b$, yield per vine; $c$, bunch mass.

The average absolute error of the model amounted to 8 days (with exception for 5 days in 2016), or $4 \%$ of the ripening time duration, which confirmed its adequacy. The accuracy of the model is evidenced by the correlation $(r=0.69)$ of the actual and calculated data. The year 2016 was characterized by an anomalous precipitation of $338 \mathrm{~mm}$ during the ripening period against the average value of $214 \mathrm{~mm}$, including the 'onset of bud break - onset of flowering' period with $182 \mathrm{~mm}$ against the perennial average of $65 \mathrm{~mm}$. This might be one of the reasons for the 17-day increase in the ripening time duration compared to the average long-term value, which is not fully explained by the model.

The rate of independent variables change in 1981-2017 was $\Delta \Sigma T_{20}=324.3^{\circ} \mathrm{C} / 10$ years, $\Delta N_{10-15}=-0.4$ days $/ 10$ years, therefore $\Delta N=-4.4$ days $/ 10$ years according to the formula (1). The model predicts a more significant ripening time reduction than the actually observed $\Delta N=-2.5$ days $/ 10$ years. The actual trend was significantly influenced by 2016 (see Fig. 3), while in 1981-2015 the actual trend showed $\Delta N=-4.3$ days $/ 10$ years, which corresponds to the calculated one. Thus, the decrease in the ripening time duration is largely due to the rising temperatures.

\section{Discussion}

The principal component analysis of the mean long term data on 21 indicators of 109 grape varieties has shown that the main differentiating phenotypic character of the ampelographic collection is the bunch and berry size, which is contrasting in the table and wine varieties. A large berry is characteristic of a group of table hybrids of $V$. vinifera with several American species. A significant part of this group is represented by varieties from the Republic of Moldova and by hybrids produced with the use of the American variety Save Villar and the Central Asian variety Katta-Kurgan. The Central Asian varieties known for large berries are absent in the used sample. The second factor, i. e. the yield and the number of fruiting shoots associated with it, winter hardiness and fruiting coefficient, is at its maximum in $V$. vinifera $\times V$. labrusca and $V$. vinifera $\times V$. amurensis hybrids, which retain winter resistance and a greater number of productivity elements from the Amur and 


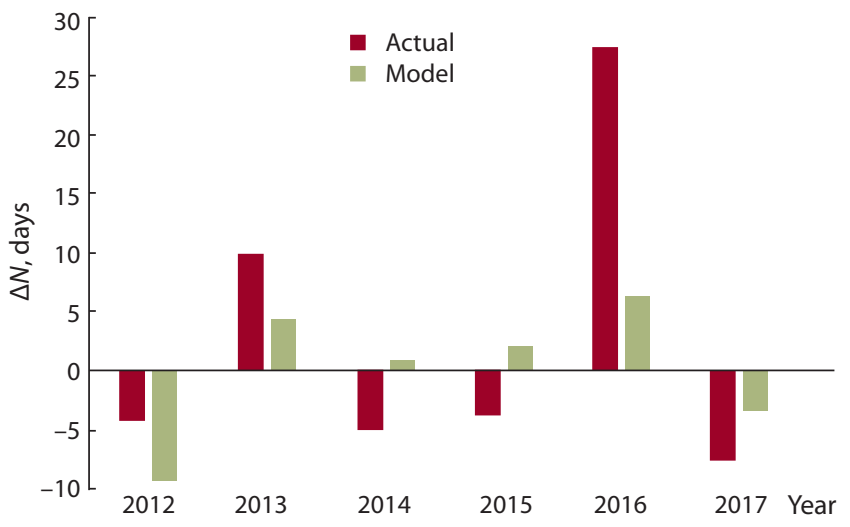

Fig. 4. Comparison of the actual and model-calculated annual increment to the grape ripening time duration $(\Delta N)$ in 2012-2017.

American species (Troshin, 1999; Nosulchak, 2015), while it is at its minimum in the European cultivated grapes. The third factor is the ripening time and interphase periods duration, and the related berry juice acidity and GAI.

The analysis of variance has confirmed a number of reliable differences of the average indicators between the groups of varieties composed according to the type of use, origin, and ripening time. The table varieties differ from the wine ones by a larger bunch and a shorter ripening time. On the average, interspecific hybrids exceed $V$. vinifer $a$ varieties in the number of productivity elements and yield. The groups of $V$. vinifera $\times V$. labrusca and $V$. vinifera $\times V$. amurensis hybrids do not differ significantly from each other by the average ripening time duration, yield and bunch mass values. The similarity of a number of characteristics of these species is noted in the literature (Negrul, 1946, p. 120). Complex hybrids with American species represent a polymorphic group and occupy an intermediate position concerning the majority of the studied parameters, with an exception for the characteristics of the bunch, between $V$. vinifera varieties and hybrids with $V$. labrusca and $V$. amurensis. The analysis of variance has confirmed the PCA-detected association of the ripening time only with the interphase periods duration, acidity, and GAI.

The analysis of trends in agrobiological indicators of homogeneous groups of varieties has confirmed that varieties do not differ in trends of the long-term dynamics of most indicators. All groups demonstrated a decrease in the ripening time duration ( 2 days/10 years on the average for 109 varieties), an increase in yield (1 kg/vine/10 years on the average) and sugar content $\left(2 \mathrm{~g} / 100 \mathrm{~cm}^{3}\right.$ on the average), a decrease in acidity (an average of $1 \mathrm{~g} / \mathrm{dm}^{3}$ ), which corresponds to the trends observed in other countries (Vršič, Vodovnik, 2012). The trends of the average indicators in the groups of varieties with different ripening time were also similarly directed. Thus, the thesis was confirmed that the impact of climate was greater than that of variety (Leeuwen et al., 2004).

The group of $V$. vinifera $\times V$. labrusca hybrids of wine type is characterized by the most significant changes, e. g., by the highest rate of the ripening time decrease (18 days/10 years), a decrease in the fruiting shoots percentage (11\%/10 years) and an increase in the mass of the bunch $(73 \mathrm{~g} / 10$ years $)$ and berry ( $3 \mathrm{~g} / 10$ years).
The model of the ripening time duration dynamics (1) was validated using the data of 2012-2017, which were not used in model creation. The trend of the ripening time duration calculated using the model was $\Delta=-4$ days/10 years, which corresponds to that observed until 2016. The increase in the ripening time duration in 2016 could not be explained by the model and was possibly due to the anomalous precipitation that year. Thus, it has been shown that the observed decrease in the varieties' ripening time duration was largely due to the growing temperatures.

\section{Conclusion}

Homogeneous groups of varieties in the ampelographic collection, composed according to the type of use, taxonomic origin and ripening time, are characterized by a similar response to the climate change. An increase in temperature in the northern zone of industrial viticulture in the Russian Federation leads to a reduction in the grapes ripening time, an increase in yield and sugar content, and a decrease in berry acidity.

\section{References}

Choudhury A., Jones J. Crop yield prediction using time series models. J. Economics Econ. Educ. Res. 2014;15(3):53-67.

Cleland E.E., Chuine I., Menzel A., Mooney H.A., Schwartz M.D. Shifting plant phenology in response to global change. Trends Ecol. Evol. 2007;22:357-365.

Code des caracteres descriptifs des varietes et especes de Vitis. Paris, 1983.

Cunha J., Teixeira Santos M., Carneiro L.C., Fevereiro P., Eiras-Dias J.E. Portuguese traditional grapevine cultivars and wild vines (Vitis vinifera L.) share morphological and genetic traits. Genet. Resour. Crop Evol. 2009;56:975-989. DOI 10.1007/s10722-009-9416-4.

Davitaya F.F. Study of the Climates of Vine in the USSR and Grounds of their Practical Application. Moscow; Leningrad, 1952. (in Russian)

Delrot S., Girollet N., Garcia V. et al. Investigating grapevine $\times$ environment interactions: data integration is the corner stone! In: INTEGRAPE 2019. Data Integration as a key step for future grapevine: Book of Abstracts. Chania, Greece, 25-28 March, 2019;17. Available at: http://www.integrape.eu/images/pdf/CA17111integrape2019.pdf

Eliseeva I.I., Kurysheva S.V., Kosteeva T.V., Pantina I.V., Mikhaylov B.A., Neradovskaya Yu.V., Stroe G.G., Bartels K., Rybkina L.R. Econometrics. Moscow, 2007. (in Russian)

Hausmann L., Maul E., Ganesch A., Kecke S., Töpfer R. The Vitis International Variety Catalogue and the European Vitis Database. In: INTEGRAPE 2019. Data Integration as a key step for future grapevine: Book of Abstracts. Chania, Greece, 25-28 March, 2019;9. Available at: http://www.integrape.eu/images/pdf/CA17111integrape2019.pdf

Iler A.M., Inouye D.W., Schmidt N.M., Høye T.T. Detrending phenological time series improves climate-phenology analyses and reveals evidence of plasticity. Ecology. 2017;98(3):647-655.

Jones G. Climate, grapes, and wine: structure and suitability in a changing climate. Acta Hortic. 2012;931:19-28. DOI 10.17660/Acta Hortic.2012.931.1.

Kelchevskaya L.S. Methods of Processing of Observations in Agroclimatology. Leningrad, 1971. (in Russian)

Lamine M., Zemni H., Ziadi S., Chabaane A., Melki I., Mejr S., Zoghlami N. Multivariate analysis and clustering reveal high morphological diversity in Tunisian autochthonous grapes (Vitis vinifera): insights into characterization, conservation and commercialization. OENO One. 2014;48(2):111-122. DOI 10.20870/oeno-one.2014.48.2.1565. Lazarevsky M.A. Role of Heat in the Life of the European Vine. Rostov-on-Don, 1961. (in Russian) 
Lazarevsky M.A. The Study of Grape Varieties. Rostov-on-Don, 1963. (in Russian)

Leão P., Cruz C., Motoike S. Genetic diversity of table grape based on morphoagronomic traits. Sci. Agric. 2011;68(1):42-49. DOI 10.1590/S0103-90162011000100007.

Leeuwen C., Friant Ph., Chone X., Tregoat O., Koundouras S., Dubourdieu D. Influence of climate, soil and cultivar on terroir. Am. J. Enol. Vitic. 2004;55(3):207-217.

Molitor D., Junl J., Evers D., Hoffmann L., Beyer M. A high-resolution cumulative degree day-based model to simulate phonological development of grapevine. Am. J. Enol. Vitic. 2014;65(1):72-80.

Naumova L.G., Novikova L.Y. Duration trends in grape varieties of the vegetation collection of Potapenko All-Russia Research Institute of Viticulture and Winemaking. Vinodelie i Vinogradarstvo $=$ Winemaking and Viticulture. 2013;6:48-53. (in Russian)

Naumova L.G., Novikova L.Y. Using the method of successive differences for creating an agrometeorological regression model of long-term data. Plodovodstvo i Yagodovodstvo Rossii $=$ Pomiculture and Small Fruit Culture in Russia. 2018;55:133-137. DOI 10.31676/2073-4948-2018-55-133-137. (in Russian)

Negrul A.M. Essay of the Grape Family and its Main Species with their Brief Economic Characterization. In: Ampelography of the USSR. Vol. 1. Moscow, 1946;45-133. (in Russian)

Nosulchak V.A. Varietal Composition of Vineyards of the USSR. Krasnodar, 2015. (in Russian)

Novikova L.Y., Naumova L.G. Trends of changes in sugar content and acidity of grape varieties from the collection of the Potapenko AllRussia Research Institute of Viticulture and Winemaking. Vinodelie i Vinogradarstvo = Wine-making and Viticulture. 2013;6:54-57. (in Russian)

Novikova L.Y., Naumova L.G. Analysis of economically valuable characters of grape varieties of different origin from the Potapenko
All-Russia Research Institute of Viticulture and Winemaking under climate change conditions. Nauchnye trudy SKFNTsSVV = Proceedings of the North Caucasian Research Institute of Horticulture and Viticulture. 2018;19:113-119. DOI 10.30679/2587-9847-201819-113-119. (in Russian)

Quenol H., Grosset M., Barbeau G., van Leeuwen K., Hofmann M., Foss Ch., Irimia L., Rochard J., Boulanger J.-Ph., Tissot C., Miranda C. Adaptation of viticulture to climate change: high resolution observation of adaptation scenario for viticulture. Bull. de l'OIV. 2014;1001-1002-1003(87):385-406.

Richardson A.D., Anderson R.S., Arain M.A. Terrestrial biosphere models need better representation of vegetation phenology: results from the North American Carbon Program Site Synthesis. Glob. Change Biol. 2012;18:566-584. DOI 10.1111/j.13652486.2011.02562.x.

Santibáñez F., Sierra H., Santibanez P. Degree day model of table grape (Vitis vinifera L.) phenology in Mediterranean temperate climates. Int. J. Sci. Environ. Technol. 2014;3(1):10-22.

Sirotenko O.D. Fundamentals of Agricultural Meteorology. Vol. 2, Book 1: Mathematical Models in Agrometeorology. Obninsk, 2012. (in Russian)

Troshin L.P. Ampelography and Grape Breeding. Krasnodar, 1999. (in Russian)

Vršič S., Vodovnik T. Reactions of grape varieties to climate changes in North East Slovenia. Plant Soil Environ. 2012;58(1):34-41.

Wenjiao S., Fulu T., Zhao Z. A review on statistical models for identifying climate contributions to crop yields. J. Geogr. Sci. 2013;23(3):567-576.

Zarmaev A.A., Borisenko M.N. Grape Breeding, Genetics and Ampelography. From theory to practice. Simferopol, 2018. (in Russian)

ORCID ID

L.Yu. Novikova orcid.org/0000-0003-4051-3671

L.G. Naumova orcid.org/0000-0002-5051-2616

Acknowledgments. The analysis of polymorphism of the collection and of the trends in the dynamics of agrobiological indicators were carried out in the framework of the State Assignment No. 0662-2019-0004. Creation of the database and of the VTS program was supported by the Grant No. 18-01600213 of the Russian Foundation for Basic Research.

Conflict of interest. The authors declare no conflict of interest.

Received May 29, 2019. Revised July 11, 2019. Accepted July 15, 2019. 